\title{
ON THE VELOCITY OF OXYGEN DISSOCIATION OF HUMAN HEMOGLOBIN AND RED CELL
}

\author{
Masaji MochIzUKI \\ Research Institute of Applied Electricity, Hokkaido University, Sapporo
}

In the preceding studies ${ }^{1,2)}$ it has been clarified that the velocity factor in. the oxygenation of the red cell is to be subdivided into two categories, i.e. the factor related to gaseous diffusion and that related to chemical reaction between $\mathrm{O}_{2}$ and $\mathrm{Hb}$. Further, it has been realized that the reciprocal of the total velocity factor equals the sum of the reciprocals of the subdivided factors. This formula may be applied not only to the oxygenation, but also to the dissociation reaction, where the $\mathrm{O}_{2}$ diffuses out of the red cell into the surrounding medium. The aim of the present study is to examine the applicability of the formula to the dissociation reaction on one hand and, on the other hand, to determine quantitatively the dissociation velocity of $\mathrm{Hb}$ in solution as well as in the red cell under physiological conditions.

In 1923, HARTRIDGE and ROUGHTON ${ }^{3)}$ measured the dissociation velocity of $\mathrm{Hb}$ solution and the red cell by using sodium hydrosulphite, $\mathrm{Na}_{2} \mathrm{~S}_{2} \mathrm{O}_{4}$, and found that the half-time of $\mathrm{O}_{2} \mathrm{Hb}$ dissociation in a laked $\mathrm{Hb}$ solution was 14 to $19 \mathrm{msec}$ at room temperature and that in the red cell was $135 \mathrm{msec}$. In 1933, MILliKAN ${ }^{4}$ measured this velocity, following the same method, but his halftimes were twice as long as those shown by HARTRIDGE and ROUGHTON. Fifteen years later, LEGGE and RoughtoN ${ }^{5)}$ studied the deoxygenation with ram blood; according to their report the half-times of $\mathrm{O}_{2} \mathrm{Hb}$ dissociation in solution were distributed around $30 \mathrm{msec}$, while those of the red cell were 170 to $210 \mathrm{msec}$ at $\mathrm{pH} 7.1$ and 140 to $160 \mathrm{msec}$ at $\mathrm{pH}$ 6.8. Recently, LAwson, HOLLAND and FORSTER ${ }^{6}$ measured the deoxygenation velocity of the red cell by combining the dithionite method and a stopped flow method elaborated by Sirs and Roughton. ${ }^{7}$ ) The half-times they found were markedly shorter, being $34 \mathrm{msec}$ at $37^{\circ} \mathrm{C}$ and $87 \mathrm{msec}$ at $6.8^{\circ} \mathrm{C}$. In 1955 , GiBson and others ${ }^{8)}$ calculated the dissociation velocity by measuring the displacement reaction of $\mathrm{O}_{2} \mathrm{Hb}+\mathrm{CO}$ and obtained $28 \mathrm{sec}^{-1}$ on an average, which corresponded to a time constant of $36 \mathrm{msec}$. Thus, the half-time of the dissociation was roughly estimated as about $23 \mathrm{msec}$. Those data which appeared in literatures are

Received for publication March 1, 1966

望月政司 
TABLE 1.

Half-times of the dissociation reaction measured by previous workers.

\begin{tabular}{|c|c|c|c|c|c|}
\hline \multirow{2}{*}{ Species } & \multirow{2}{*}{$\begin{array}{l}\text { Temp. } \\
\left({ }^{\circ} \mathrm{C}\right)\end{array}$} & \multicolumn{2}{|c|}{ Half-time (msec) } & \multirow{2}{*}{ Method } & \multirow{2}{*}{ Author } \\
\hline & & Solution & Red cell & & \\
\hline Sheep & 15 & 35 & 135 & adding $\mathrm{Na}_{2} \mathrm{~S}_{2} \mathrm{O}_{4}$ & RoughtoN $(1926)^{3)}$ \\
\hline , & 22 & 14 & & $"$ & , \\
\hline Man & 22 & 19 & & , & , \\
\hline Sheep & 22 & 28 & & , & MiLliKAN $(1933)^{4)}$ \\
\hline Man & 22 & 38 & & , &, \\
\hline Pig & 22 & 47 & &, & , \\
\hline Ram & 15 & 30 & 140 & $"$ & $\begin{array}{l}\text { LEGGE \& } \\
\text { Roughton }(1949)^{5)}\end{array}$ \\
\hline$"$ & 13.5 & $30-50$ & $160-210$ & , & " \\
\hline , & 14 & 30 & $120-170$ & , & , \\
\hline Man & 18 & 23 & & adding $\mathrm{CO}$ in $\mathrm{O}_{2} \mathrm{Hb}$ & $\begin{array}{l}\text { GIBSON, et al. } \\
(1955)^{8)}\end{array}$ \\
\hline , & 37 & & 34 & adding $\mathrm{Na}_{2} \mathrm{~S}_{2} \mathrm{O}_{4}$ & $\begin{array}{l}\text { LAwsON, et al. } \\
(1964)^{6)}\end{array}$ \\
\hline ", & 6.8 & & 13 & $"$ & , \\
\hline ", & 37 & & 13 & $\begin{array}{l}\text { mixing with low } \\
\mathrm{P}_{\mathrm{O}_{2}} \text { sol. }\end{array}$ & $\begin{array}{l}\text { NAKAMURA \& } \\
\text { STAUB }(1964)^{10)}\end{array}$ \\
\hline
\end{tabular}

summarized in TABLE 1.

In the method using dithionite the $\mathrm{O}_{2}$ tension in the medium was neglected, and, furthermore, according to GIBSON ${ }^{9}$ there was a side reaction between the oxidation products of dithionite and $\mathrm{Hb}$. Therefore, the experimental conditions in the dithionite methed seems to be far different from the physiological conditions to be considered in the peripheral capillaries. In 1964, NAKAMURA and STAUB ${ }^{10}$, measured the deoxygenation of the red cell by use of $\mathrm{P}_{\mathrm{O}}$, measurement by a $\mathrm{Pt}$ electrode. The half-times observed were very short and were ranged from 16 to $10 \mathrm{msec}$. These values were $1 / 2$ to $1 / 3$ of the shortest values so far obtained.

\section{METHOD}

A similar method described in the previous paper ${ }^{2}$ was used in this experiment, except that compositions of the gases used for tonometry were different and the oxygenated $\mathrm{Hb}$ solution as well as the oxygenated red cell suspension were mixed with $\mathrm{O}_{2}$ free buffer solution. The $\mathrm{P}_{\mathrm{O}_{2}}$ and $\mathrm{P}_{\mathrm{CO}_{2}}$ of the mixed gases are tabulated in TABLE 2. $\mathrm{P}_{\mathrm{O}_{2}}$ 's of higher oxygen group were 23 and $32 \mathrm{mmHg}$ in case of $\mathrm{Hb}$ solution and were 88,68 and $61 \mathrm{mmHg}$ in case of the red cell experiment. $\mathrm{P}_{\mathrm{O}_{2}}$ 's of lower oxygen group were 1.6 and $3.2 \mathrm{mmHg}$. $\mathrm{P}_{\mathrm{CO}_{2}}$ was kept at about $40 \mathrm{mmHg}$ throughout this experiment. $\mathrm{pH}$ of $\mathrm{Hb}$ solution was 7.26 and that of the red cell suspension was 7.40 . 
TABle 2 .

Compositions of mixed gases used for tonometry.

\begin{tabular}{|c|c|c|c|c|c|c|c|}
\hline & \multirow{2}{*}{ No. } & \multirow{2}{*}{$\begin{array}{l}\text { Number } \\
\text { of } \\
\text { Subjects }\end{array}$} & \multirow{2}{*}{ Date } & \multicolumn{2}{|c|}{$\begin{array}{l}\text { High } \mathrm{P}_{\mathrm{O}_{2}} \text { gas } \\
(\mathrm{mmHg})\end{array}$} & \multicolumn{2}{|c|}{$\begin{array}{c}\text { Low } \mathrm{P}_{\mathrm{O}_{2}} \text { gas } \\
(\mathrm{mmH})\end{array}$} \\
\hline & & & & $\mathrm{P}_{\mathrm{O}_{2}}$ & $\mathrm{P}_{\mathrm{CO}_{2}}$ & $\mathrm{P}_{\mathrm{O}_{2}}$ & $\mathrm{P}_{\mathrm{CO}_{3}}$ \\
\hline & 1 & 3 & Nov. $18-22$ & 32 & 40 & 1. 6 & 39 \\
\hline $\mathrm{Hb}$ & 2 & 4 & $\begin{array}{l}\text { Nov. } 27-28 \\
\text { Dec. } 8\end{array}$ & 23 & 40 & 3.2 & 40 \\
\hline \multirow{3}{*}{$\begin{array}{l}\text { Red } \\
\text { cell }\end{array}$} & 1 & 3 & Oct. $7-8$ & 88 & 42 & 1.6 & 46 \\
\hline & 2 & 4 & Oct. $10-13$ & 68 & 35 & 3.2 & 40 \\
\hline & 3 & 3 & Oct. 11-14 & 61 & 39 & 1.6 & 46 \\
\hline
\end{tabular}

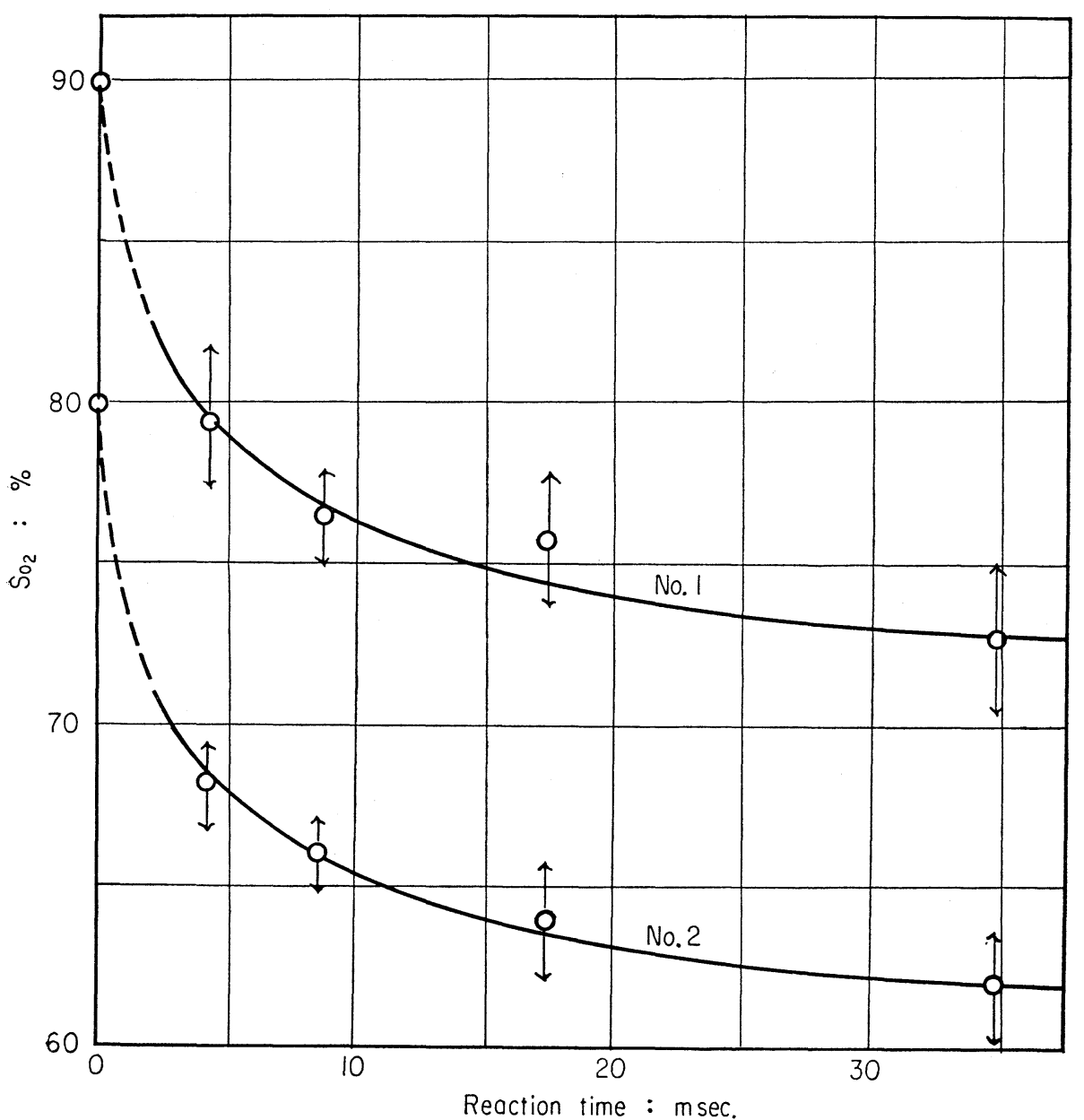

FIG. 1. Changes of $\mathrm{S}_{\mathrm{O}_{2}}$ due to the dissociation of $\mathrm{O}_{2} \mathrm{Hb}$ in laked $\mathrm{Hb}$ solution. The numbers on the curve show the experiment number of TABLE 2. 


\section{RESULTS}

1) Hb solution. The deoxygenation was measured with samples collected from three or four normal subjects and in the two cases of No. 1 and 2 of different $\mathrm{S}_{\mathrm{O}_{2}}$ range as shown in TABLE 1 . The $\mathrm{S}_{\mathrm{O}_{2}}$ changes plotted along the reaction time are shown in FIG. 1. The plots are the means of 6 or 8 respective measurements and the arrows show the standard deviations around the means. The deviations were 1.0 to $2.3 \%$ in $\mathrm{S}_{\mathrm{O}_{2}}$.

The velocities shown in this figure were very fast in comparison with the data previously measured. Two thirds of the changes of $\mathrm{S}_{\mathrm{O}_{2}}$ were finished within $5 \mathrm{msec}$ after mixing. The $\mathrm{S}_{\mathrm{O}}$ decreased at first exponentially with a lapse of time. As the reaction proceeded, however, it deviated from the exponential curve. Actually, the changing rate, dS/dt, was proportional to the 1.6th power of the difference between the real $\mathrm{S}_{\mathrm{O}_{2}}$ of $\mathrm{Hb}, \mathrm{S}$, and the supposed $\mathrm{S}_{\mathrm{O}_{2}}$ corresponding to the $\mathrm{P}_{\mathrm{O}_{2}}$ of the surrounding medium, $\mathrm{S}_{\mathrm{m}}$, as shown in FIG. 2. The $\mathrm{S}_{\mathrm{m}}$ was obtained from the $\mathrm{P}_{\mathrm{O}_{2}}$ in the medium by referring to the $\mathrm{O}_{2}$ dissociation curve of $\mathrm{Hb}$ solution shown in FIG. 5 of the previous paper ${ }^{1)}$. The

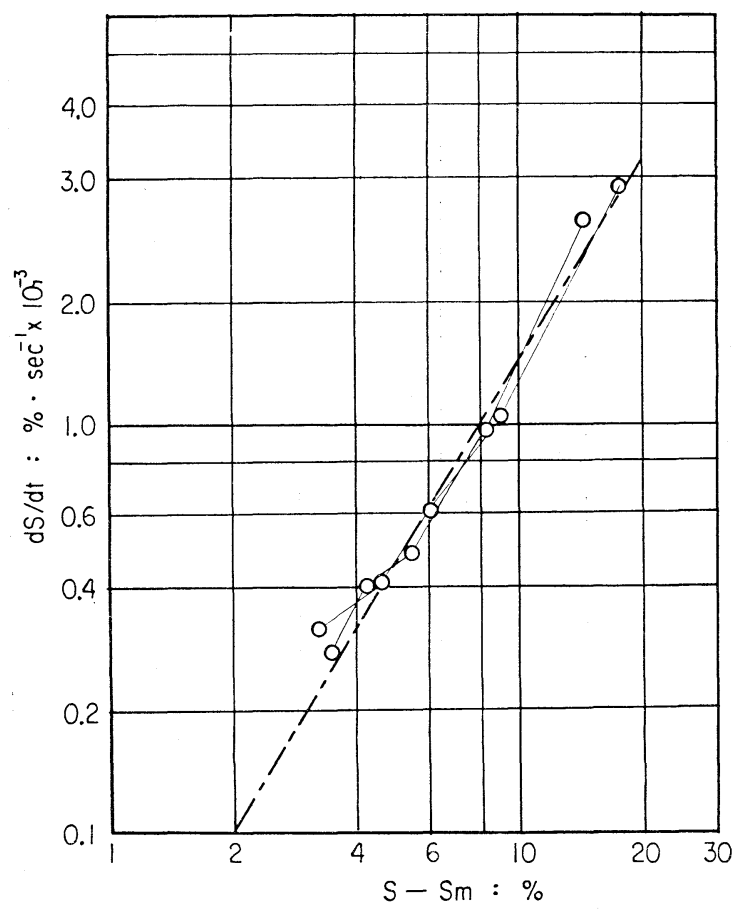

FIG. 2. Time rate of $\mathrm{S}_{\mathrm{O}}$, changes, dS/dt, plotted against the difference between the real $\mathrm{S}_{\mathrm{O}_{2}}$ of $\mathrm{Hb}, \mathrm{S}$, and the supposed $\mathrm{S}_{\mathrm{O}_{2}}$ corresponding to $\mathrm{P}_{\mathrm{O}_{2}}$ of the surrounding medium, $S_{m}$, which was obtained by referring to the $\mathrm{O}_{2}$ dissociation curve published on the previous paper.1) 
relation shown in FIG. 2 is expressed numerically by

$$
\mathrm{dS} / \mathrm{dt}=63.4\left(\mathrm{~S}-\mathrm{S}_{\mathrm{m}}\right)^{1.6} .
$$

As is clear from $\mathrm{Eq}(1)$, the deoxygenation velocity had no distinct relation to the $\mathrm{P}_{\mathrm{O}_{2}}$ difference between the medium and $\mathrm{Hb}$, that is, to the difference between the real $\mathrm{P}_{\mathrm{O}_{2}}$ and the back pressure. The latter $\mathrm{P}_{\mathrm{O}}, \mathrm{P}_{\mathrm{Hb}}$, was obtained from the $\mathrm{O}_{2}$ dissociation curve of $\mathrm{Hb}$ solution by referring to the $\mathrm{S}_{\mathrm{O}_{2}}$. In other words, the velocity factor of deoxygenation in $\mathrm{Hb}$ solution, $\mathrm{F}_{\mathrm{s}}{ }^{\prime}$, which was obtained according to the following formula (refer to $\mathrm{Eq}(1)$ in the previous paper ${ }^{2)}$ ) was no longer independent of the $\mathrm{P}_{\mathrm{O}_{3}}$ difference, $\mathrm{P}_{\mathrm{Hb}}-\mathrm{P}$, where $\mathrm{P}$ represents the real $\mathrm{P}_{\mathrm{O}_{2}}$ of solution.

$$
\mathrm{F}_{\mathrm{s}}{ }^{\prime}=-\frac{0.4 \times 10^{-2} \cdot \mathrm{dS} / \mathrm{dt}}{\mathrm{P}_{\mathrm{Hb}}-\mathrm{P}}
$$

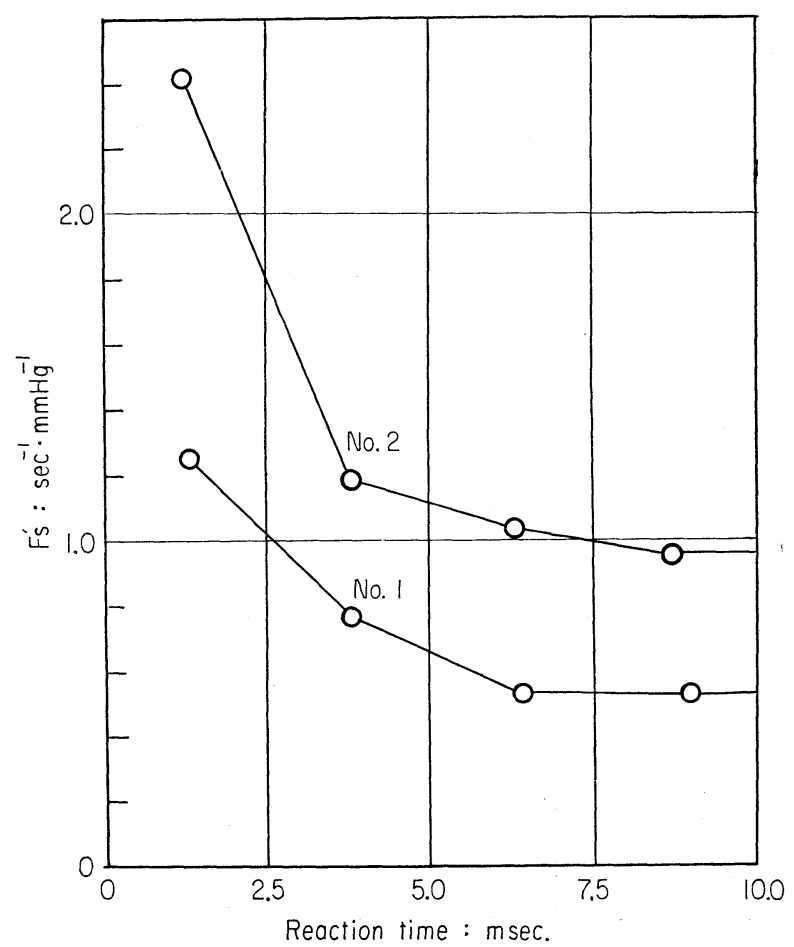

FIG. 3. Deoxygenation velocity factor of $\mathrm{Hb}, \mathrm{F}_{\mathrm{s}}$ ', plotted against the reaction time. The velocity factor was obtained through

$$
\mathrm{F}_{\mathrm{s}}{ }^{\prime}=-\frac{0.4 \times 10^{-2} \cdot \mathrm{dS} / \mathrm{dt}}{\mathrm{P}_{\mathrm{Hb}}-\mathrm{P}}
$$

where $\mathrm{P}_{\mathrm{Hb}}$ was derived from the $\mathrm{O}_{2}$ dissociation curve of $\mathrm{pH} 7.26$ by referring to $\mathrm{S}_{\mathrm{O}_{z}}$ of $\mathrm{Hb}$. 
The $\mathrm{F}_{\mathrm{s}}{ }^{\prime}$ decreased with decrease of the $\mathrm{P}_{\mathrm{O}}$, difference, that is, it was high at the beginning of the reaction and decreases gradually as shown in FIG. 3. The $F_{\mathrm{s}}{ }^{\prime}$ values in FIG. 3 were calculated at every $2.5 \mathrm{msec}$ intervals along two curves of FIG. 1.

On the other hand, it was a function of $\mathrm{S}_{\mathrm{O}_{3}}$; it increased as $\mathrm{S}_{\mathrm{O}_{2}}$ decreased. However, it did not become smaller than $0.5 \mathrm{sec}^{-1} \cdot \mathrm{mmHg}^{-1}$ even at the $\mathrm{So}_{2}$ range over $90 \%$. In other words, the velocity factor in the deoxygenation of $\mathrm{O}_{2} \mathrm{Hb}$ in solution was always greater 20 times that of the velocity factor for $\mathrm{O}_{2}$ diffusion inside the red cell, $0.025 \mathrm{sec}^{-1} \cdot \mathrm{mmHg}^{-1}$ which was observed in the preceding paper ${ }^{2}$.

2) Red cell suspension. The deoxygenation velocity of the red cell was measured with five normal subjects under three conditions as shown in TABLE

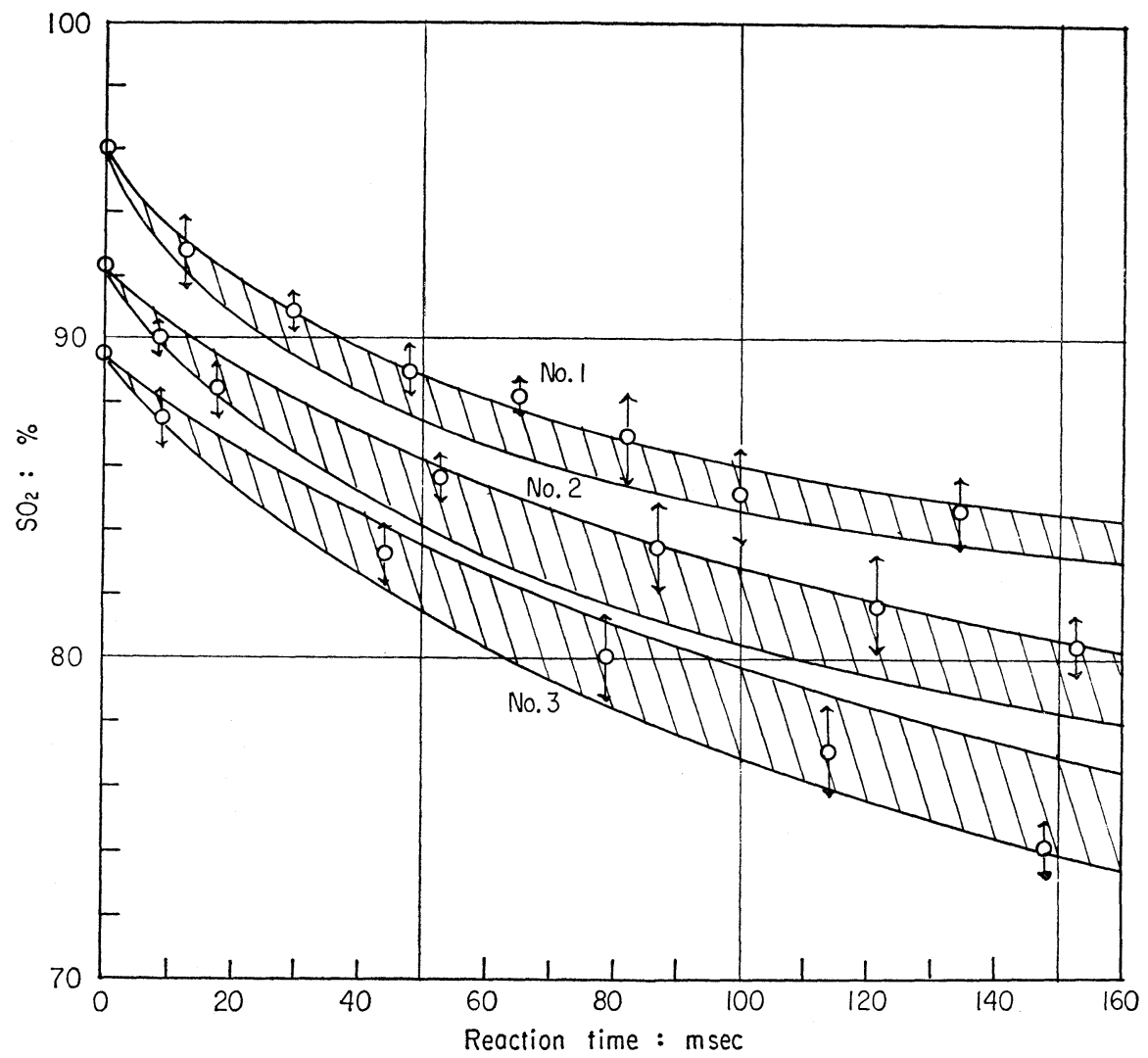

FIG. 4. Changes of $\mathrm{S}_{\mathrm{O}_{2}}$ of the red cell due to the dissociation reaction. The two curves bordering the shaded areas were obtained by numerical integration of

$$
\mathrm{dS} / \mathrm{dt}=\mathrm{F}_{\mathrm{c}}{ }^{\prime}\left(\mathrm{P}_{\mathrm{c}}-\mathrm{P}\right) / 0.4 \times 10^{-2},
$$

where $\mathrm{F}_{\mathrm{c}}$ 's were constantly taken as $0.02 \mathrm{sec}^{-1} \cdot \mathrm{mmHg}^{-1}$ for the upper curves and $0.03 \mathrm{sec}^{-1} \cdot \mathrm{mmHg}^{-1}$ for the lower curves. 
2. The changes of $\mathrm{S}_{\mathrm{O}_{2}}$ are plotted in FIG. 4 against the reaction time. The standard deviations around the means around the means plotted were about $1.2 \%$ in $\mathrm{S}_{\mathrm{O}_{2}}$. Each of the three series of plotted points was almost involved inside the respective shaded area between the two border curves. These curves were obtained by numerical integration of the following equation,

$$
\mathrm{dS} / \mathrm{dt}=\mathrm{F}_{\mathrm{c}}{ }^{\prime}\left(\mathrm{P}_{\mathrm{c}}-\mathrm{P}\right) / 0.4 \times 10^{-2},
$$

where $\mathrm{P}_{c}$ is $\mathrm{P}_{\mathrm{O}_{2}}$ in the red cell, $\mathrm{P}$ that of the medium and $\mathrm{F}_{\mathrm{c}}{ }^{\prime}$ is the velocity factor of deoxygenation of the red cell. In calculation of the upper curve in FIG. $4, \mathrm{~F}_{\mathrm{c}}{ }^{\prime}$ was constantly taken as $0.02 \mathrm{sec}^{-1} \cdot \mathrm{mmHg}^{-1}$ and in that of the lower curves it was $0.03 \mathrm{sec}^{-1} \cdot \mathrm{mmHg}^{-1}$. In the No. 1 and 2 experiments the plotted points lined up almost along the curve of $F_{c}{ }^{\prime}=0.02 \mathrm{sec}^{-1} \cdot \mathrm{mmHg}^{-1}$, but in the third experiment, the points were distributed between the upper and lower curves. Obviously the deoxygenation in the last case was faster than in other cases. On the other hand, the deoxygenation velocity in each case seemed to be greater at the beginning of the reaction, for the plotted $\mathrm{S}_{\mathrm{O}_{2}}$ points at the early time were always closer to the curve of $\mathrm{F}_{\mathrm{c}}{ }^{\prime}=0.03 \mathrm{sec}^{-1} \cdot \mathrm{mmHg}^{-1}$ than at the later time of reaction. This fact is supposed to reflect the characteristic of $\mathrm{F}_{\mathrm{s}}{ }^{\prime}$ shown in FIG. 3.

In general, the deoxygenation took longer time as $\mathrm{S}_{\mathrm{O}_{2}}$ decreased. Hence, the half-time grew longer with the decrease of $\mathrm{S}_{\mathrm{O}_{2}}$. The half-times obtained from the three curves from top to bottom in FIG. 4. were 35, 50 and $65 \mathrm{msec}$ respectively. These values were similar to those shown by LAwson and others. However, they are not so long as those of RougHTON and his coworkers.

\section{DISCUSSION}

The deoxygenation velocity has widely been measured by ROUGHTON and his group, but it was always measured in a solution with dithionite. Hence, it may be reasonable that the data presented here are largely different from theirs. The main differences between ours and theirs may be focussed on two points, i. e. 1) the rapidity of the reaction, and 2) the dependency of the velocity upon $\mathrm{S}_{\mathrm{O}_{2}}$, as far as the dissociation reaction of $\mathrm{O}_{2} \mathrm{Hb}$ in laked solution was concerned.

The dissociation velocity of $\mathrm{O}_{2} \mathrm{Hb}$ in laked solution was very fast and the reaction was completed within $40 \mathrm{msec}$. The half-time of dissociation was less than $5 \mathrm{msec}$. On the other hand, the rate of $\mathrm{S}_{\mathrm{O}_{2}}$ change, $\mathrm{dS} / \mathrm{dt}$, was not linearly proportional to $\mathrm{S}_{\mathrm{O}_{3}}$, but to the 1.6 th power of the $\mathrm{S}_{\mathrm{O}_{3}}$ difference between the surrounding medium and $\mathrm{Hb},\left(\mathrm{S}-\mathrm{S}_{\mathrm{m}}\right)$. In other words, the deoxygenation of $\mathrm{O}_{2} \mathrm{Hb}$ has also a non-linear relation against the $\mathrm{S}_{\mathrm{O}_{2}}$. As described in the foregoing papers ${ }^{1,2}$, the velocity factor of the oxygenation of $\mathrm{Hb}$ in solution was given experimentally by the following equation, 


$$
\mathrm{F}_{\mathrm{s}}=1.06 \times 10^{-3} \cdot\left(100-\mathrm{SO}_{\mathrm{O}_{2}}\right)^{1.6} .
$$

Therefore, the number of the power, 1.6 just agreed in both the reactions of oxy- and deoxygenation.

As to the deoxygenation of the red cell, it must be emphasized that the $\mathrm{S}_{\mathrm{O}}$, points plotted in FIG. 4 were distributed between two $\mathrm{S}_{\mathrm{O}_{2}}$-time curves calculated with $\mathrm{F}_{\mathrm{c}}{ }^{\prime}=0.02$ and $0.03 \mathrm{sec}^{-1} \cdot \mathrm{mmHg}^{-1}$. FIG. 6 in the preceding paper $^{2)}$ showed that the velocity factor of its oxygenation was in the range from 0.02 and $0.03 \mathrm{sec}^{-1} \cdot \mathrm{mmHg}^{-1}$, when the combination reaction of $\mathrm{O}_{2}$ and $\mathrm{Hb}$ was very fast. Analogously, since the velocity factor for the diffusion should be independent of the direction of diffusion, the velocity factor of deoxygenation was expected to approach some value between 0.02 and 0.03 $\mathrm{sec}^{-1} \cdot \mathrm{mmHg}^{-1}$, when the dissociation of $\mathrm{O}_{2} \mathrm{Hb}$ would occur very fast. In reality, from FIG. 4 it is conceivable that the dissociation velocity was very fast, and, thus, the velocity factor agreed well with the diffusion factor.

As seen in TABLE 1, the half-times of deoxygenation of the red cell obtained by NAKAMURA and STAUB were $1 / 3$ to $1 / 5$ of those obtained in this study. This difference seems to be due to the difference in the method used. In the method using the $\mathrm{P}_{\mathrm{O}_{2}}$ measurement, $\mathrm{P}_{\mathrm{O}_{2}}$ in solution must change with the lapse of the reaction time, in other words, the concentration of red cells in suspension should be increased high enough as $\mathrm{P}_{\mathrm{O}_{2}}$ change could be detected. Thus, the $\mathrm{P}_{\mathrm{O}_{2}}$ increase caused by the $\mathrm{S}_{\mathrm{O}_{2}}$ decrease might result in an early stop of the reaction, namely, a shorter half-time.

Apart from the kinetics of the deoxygenation, the velocity factor of deoxygenation is very important in considering the velocity of $\mathrm{O}_{2}$ supply in the peripheral capillary. In $1922, \mathrm{KROGH}^{11}$ studied the $\mathrm{O}_{2}$ diffusion in tissues using a model of a standard cylinder. In his study, the deoxygenation of the red cell was assumed to be so rapid as to be disregarded. Actually, however, the $\mathrm{P}_{\mathrm{O}_{2}}$ in blood plasma must be, more or less, lower than that of the red cell. In general, it is very difficult to calculate the $\mathrm{P}_{\mathrm{O}_{2}}$ distribution in the standerd cylinder, as stated by THEwS ${ }^{12}$. However, a rough estimation of the average $\mathrm{P}_{\mathrm{O}_{2}}$ difference between the red cell and the blood plasma may be attained from $\mathrm{Eq}$ (3) as follows.

Let the volume of red cells flowing per min through the tissue of $1 \mathrm{ml}$ be $\mathrm{Q}$, the contact time, $\mathrm{T}_{c}$ and the average $\mathrm{P}_{\mathrm{O}_{2}}$ difference between the red cell and the plasma, $\overline{\mathrm{P}_{\mathrm{c}}-\mathrm{P}_{\mathrm{p}}}$, then the $\mathrm{O}_{2}$ consumption of the tissue per min, $\dot{\mathrm{V}}_{\mathrm{O}_{2}}$, may be given by

$$
\mathrm{Q} \cdot \mathrm{T}_{\mathrm{c}} \cdot \mathrm{F}_{\mathrm{c}}{ }^{\prime}\left(\overline{\mathrm{P}_{\mathrm{c}}-\mathrm{P}_{\mathrm{p}}}\right)=\dot{\mathrm{V}}_{\mathrm{O}_{2}} \cdot
$$

Therefore, if $\mathrm{F}_{\mathrm{c}}{ }^{\prime}=0.025 \mathrm{sec}^{-1} \mathrm{mmHg}^{-1}, \mathrm{Q}=0.05 \mathrm{ml} \cdot \mathrm{min}^{-1}, \mathrm{~T}_{\mathrm{c}}=0.5 \mathrm{sec}, \mathrm{O}_{2}$ consumption $=0.5 \mathrm{Vol} \%$ of the tissue, then the average, $\mathrm{P}_{\mathrm{O}_{2}}$ difference $\overline{\mathrm{P}_{\mathrm{c}}-\mathrm{P}_{\mathrm{p}}}$, will be calculated as $6.4 \mathrm{mmHg}$. According to KROGH the $\mathrm{P}_{\mathrm{O}_{2}}$ difference between the capillary surface and the points at the greatest distance from the 
capillary was about $40 \mathrm{mmHg}$. Hence, the difference of $6.4 \mathrm{mmHg}$ is considered not to be too small.

\section{SUMMARY}

The deoxygenation velocities of $\mathrm{Hb}$ solution and the red cell suspension have been measured at $37^{\circ} \mathrm{C}$ by mixing the oxygenated $\mathrm{Hb}$ and red cells with an $\mathrm{O}_{2}$ free solution.

The dissociation of $\mathrm{O}_{2} \mathrm{Hb}$ in hemolysed solution occurred very fast and the half-time was within $5 \mathrm{msec}$. Moreover, it was clarified that the rate of change in $\mathrm{S}_{\mathrm{O}_{2}}$ of $\mathrm{Hb}$ solution obeyed the following formula,

$$
\mathrm{dS} / \mathrm{dt}=63.4\left(\mathrm{~S}-\mathrm{S}_{\mathrm{m}}\right)^{\mathbf{1 . 6}},
$$

where $\mathrm{S}_{\mathrm{m}}$ is the $\mathrm{S}_{\mathrm{O}_{2}}$ corresponding to $\mathrm{P}_{\mathrm{O}_{2}}$ of the surrounding medium.

In the red cell suspension, the reaction proceeded comparatively slowly and the half-times were ranged from 35 to $65 \mathrm{msec}$. The rate of $\mathrm{S}_{\mathrm{O}_{2}}$ change was expressed by use of the velocity factor, $F_{c}{ }^{\prime}$, as follows:

$$
\mathrm{dS} / \mathrm{dt}=\mathrm{F}_{\mathrm{c}}{ }^{\prime}\left(\mathrm{P}_{\mathrm{c}}-\mathrm{P}_{\mathrm{m}}\right) / 0.4 \times 10^{-2},
$$

where $\mathrm{P}_{\mathrm{c}}$ and $\mathrm{P}_{\mathrm{m}}$ are the $\mathrm{P}_{\mathrm{O}_{2}}$ in the red cell and the medium respectively. $\mathrm{F}_{\mathrm{c}}{ }^{\prime}$ seemed to be fairly constant and it did not deviate out of the range of 0.02 to $0.03 \mathrm{sec}^{-1} \cdot \mathrm{mmHg}^{-1}$.

\section{REFERENCES}

1) Mochizuki, M., Nakamura, K. and Oyama, Y., Jap. J. Physiol. 15, 519, 1966.

2) Mochizuki, M., ibid. 16, 635, 1966.

3) Hartridge, H. And Roughton, F. J. W., J. Physiol. 62, 232, 1926.

4) Millikan, G. A., J. Physiol., 79, 158, 1933.

5) Legge, J. W. And Roughton, F. J. W., Biochem. J. 47, 43, 1950.

6) Lawson, W. H., Holland, R. A. B. and Forster, R. E., Fed. Proc. 21, 442, 1962.

7) Sirs, J. A. And Roughton, F. J. W., J. Appl. Physiol. 18, 158, 1963.

8) Gibson, Q. H., Kreuzer, F., Meda, E. And Roughton, F. J. W., J. Physiol. 129, 65, 1955.

9) Gibson, Q. H., Progress in Biophysics, 9, 1, 1959.

10) Nakamura, T. and Staub, N. C., J. Physiol. 173, 161, 1964.

11) KROGH, A., "The anatomy and physiology of capillaries", p266, Hafner Publishing Co. New York, 1930.

12) Thews, G., Acta Biotheor. (Leiden) 10, 105, 1953. 